\title{
ANALISIS KEBUTUHAN TENAGA KERJA RESERVASI TERHADAP PERENCANAAN PENGEMBANGAN SUMBER DAYA MANUSIA PADA CV. CAN TOUR \& TRAVEL
}

\author{
Maya Christina \\ I Made Kusuma Negara \\ I Wayan Suardana \\ Email : my_hope_psiko@yahoo.com \\ PS. S1 Industri Perjalanan Wisata \\ Fakultas Pariwisata UNUD
}

\begin{abstract}
Employment remains the fundamental probel faced by many countries including Indonesia. One of the efforts the Government of Indonesia in extending employment opportunities is to develop the tourism sector. Bali is one of the potential tourist destinastions and it needs to be marketed. Cooperation between the Travel Bureau with the provider of the accommodation or hotel is one of the ways the potential market and the most instrumental in the development of the company, namely human resources required or called by labor. CV. CAN Tour and Travel is one of the tourist industry in Bali trip with a number of guest handling that quite a lot.

This research aims to know the availability of labor needs resevartion in order CV. CAN Tour and Travel development and also to find out how the workforce qualification is required. Determination technique using the key informant that was labor reservation $C V$. CAN Tour and Travel, while the base of the informant was CV. CAN Tour and Travel Manager. Data analysis technique used is the analysis of workload and workforce needs analysis.

The research results obtained indicate that shortage of time working as many as 210 minutes. So the manpower needed by $C V$. CAN Tour and Travel is two people with the fact that there is only 1 nowaday. It can be seen from the burden of the work done in a day's work and the workforce absences. So labor needs on the Reservation Department is supposed to be 3 people, with 2 staff 1 reservations and ticketing staff. It was necessary increase manpower in the Labour Departmen's Reservation in the reservation and also training to develop the ability to work.
\end{abstract}

Keywords: Needs, Qualification, and Developing.

\section{PENDAHULUAN}

Kesempatan kerja masih menjadi masalah mendasar yang dihadapi oleh banyak negara termasuk Indonesia. Di Indonesia, masalah kesempatan kerja telah ditangani serius oleh pemerintah. Salah satu upaya pemerintah Indonesia dalam memperluas kesempatan kerja adalah dengan mengembangkan sektor pariwisata. Sektor pariwisata yang melibatkan berbagai elemen didalamnya akan membutuhkan banyak tenaga kerja guna untuk memberikan pelayanan yang maksimal kepada wisatawannya.
Salah satu tempat yang dapat menjadi lahan perluasan kesempatan kerja adalah Bali. Hal ini disebabkan oleh daya tarik Bali yang memiliki budaya yang sangat kuat dan khas, adat-istiadat dan juga kesenian yang beraneka ragam, sehingga semakin banyak pula industri di dalamnya.

Berdasarkan data yang didapat dari Dinas Pariwisata Propinsi Bali tahun 2013 dinyatakan bahwa jumlah kunjungan wisatawan ke Provinsi Bali periode tahun 2008 - 2012 meningkat dari tahun ke tahun. Wisatawan yang dimaksud 
diatas mencakup wisatawan mancanegara maupun domestik yang mengalami peningkatan. Potensi ini dapat mendorong usaha-usaha pariwisata untuk lebih berkembang. Sebagai salah satu daya tarik wisata dunia, perlu upaya lebih lagi untuk memperbaiki sistem industri pariwisata agar sistem ini pun dapat memperbaiki perekonomian di daerah Bali. Salah satu upaya yang dapat dilakukan adalah dengan meningkatkan kualitas yang ada pada setiap bidang usaha pariwisata yang berdiri di Bali, disini lebih mengarah kepada bidang usaha jasa yang banyak terlibat menjadi ujung tombak aliran wisata yaitu Biro Perjalanan Wisata.

Salah satu biro perjalanan wisata di Bali yang akan dibahas adalah CV. CAN Tour and Travel. Dilihat dari data tamu yang menggunakan jasa biro tersebut dibandingkan dengan jumlah tenaga kerja yang ada di perusahaan tersebut. Dengan alasan itulah, peneliti mengangkat judul penelitian ini karena dalam CV. CAN Tour and Travel masih terdapat kurangnya manajemen sumber daya manusia khususnya staff reservasi pada Reservation Department, didalamnya guna untuk meningkatkan kualitas perusahaan ataupun kualitas sumber daya manusia itu sendiri.

\section{TINJAUAN PUSTAKA}

Biro Perjalanan menurut Surat Keputusan Direktur Jenderal Pariwisata No. Kep.16/U/II/88 Tgl 25 Februari 1988 tentang pelaksanaan Ketentuan Usaha Perjalanan, pada Bab I Penelitian Umum Pasal I , biro perjalanan umum adalah badan usaha yang menyelenggarakan kegiatan usaha perjalanan ke dalam negeri dan atau ke luar negeri.

Pengertian sumber daya manusia dalam penelitian ini didapat dari beberapa sumber seperti yang dikatakan Mathis dan Jackson (2006 : 3)bahwa SDM atau sumber daya manusia adalah rancangan sistem-sistem formal dalam sebuah organisasi untuk memastikan penggunaan bakat manusia secara efektif dan efisien guna mencapai tujuan organisasi.

Demikian pula menurut The Chartered Institute of Personnel and Development (CIPD) dalam Mullins (2005 : 422). Sumber daya manusia dinyatakan sebagai strategi perancangan, pelaksanaan dan pemeliharaan untuk mengelola manusia untuk kinerja usaha yang optimal termasuk kebijakan pengembangan dan proses untuk mendukung strategi.

Sehingga pengertian sumber daya manusia dalam penelitian ini adalah suatu sumber yang berasal dari kekuatan yang dimiliki manusia untuk menjalankan sebuah organisasi dengan mengatur kelompok organisasi tersebut secara efektif agar perusahaan dapat mencapai tujuan yang telah ditentukan oleh perusahaan sebagai visi.

Perencanaan merupakan inti dari manajemen seperti yang dikatakan oleh Siagian (2002:41) yang mengemukakan bahwa perencanaan pada dasarnya merupakan pengambilan keputusan sekarang tentang hal hal yang akan dikerjakan di masa depan. Namun dalam pembahasan mengenai sumber daya manusia, lebih tertuju kepada langkah - langkah yang diambil oleh manajemen agar ketersediaan tenaga kerja yang tepat untuk menduduki berbagai jabatan dan pekerjaan yang tepat pada waktu yang tepat.

Untuk menghadapi tuntutan tugas sekarang dan terutama untuk menjawab tantangan masa depan, pengembangan sumber daya manusia merupakan suatu keharusan mutlak. Siagian (2002 : 182) mengatakan bahwa kemampuan pegawai baru yang digabung dengan program pengenalan dan pelatihan tertentu belum sepenuhnya menjamin hilangnya kesenjangan antara kemampuan kerja dan tuntutan tugas. Itulah titk penting adanya pengembangan sumber daya manusia.

Menurut Utama (2001 : 93), analisis kebutuhan tenaga kerja adalah suatu proses penentuan tenaga kerja yang dibutuhkan untuk dapat mempertahankan kontinuitas kegiatan perusahaan secara normal. Analisis kebutuhan tenaga kerja dapat dinyatakan dengan rumus (Winaya,1994:30) : Work Force Analysis = Work Load Analysis + \%Absenteeism WLA + \% Labour Turn Over WLA

Dapat dikatakan bahwa setelah tanggung jawab, kondisi kerja dan persyaratan kerja dari pemegang jabatan diketahui, maka beban kerja dan jumlah kebutuhan serta sumber daya manusia. Dengan ini, pemenuhan kebutuhan tenaga kerja dapat diketahui dari jumlah jam kerja pegawai tersebut dan juga tingkat absensi pegawai tersebut. Tenaga Kerja $=$ Beban Kerja + 
(Tk.Absensi+Tk.Perputaran Tenaga Kerja) x Beban Kerja

Untuk mengetahui secara lebih pasti jumlah kebutuhan tenaga kerja perlu diperhatikan tingkat absensi dan tingkat perputaran pegawai. Hal tersebut penting, jika mengingat pasti pernah pegawai tersebut absen dan mengalami perputaran. Berikut penjelasannya :

1. Tingkat Absensi

Tingkat absensi yang makin besar, dengan kata lain makin banyak tenaga kerja yang tidak masuk kerja, akan semakin menyulitkan organisasi mencapai target perusahaan. Tingkat absensi merupakan perbandingan antara hari - hari yang hilang dengan keseluruhan hari yang tersedia untuk bekerja. Tingginya tingkat absensi akan merugikan organisasi, meskipun seandainya karyawan tersebut tidak dibayar sewaktu tidak masuk kerja. Hal itu terjadi karena jadwal kerja terpaksa tertunda, mutu barang cenderung berkurang, terpaksa melakukan kerja lembur dan jaminan sosial juga masih harus dibayarkan. Karena itu perusahaan akan berusaha untuk menekan tingkat absensi. Tingkat absensi yang dianggap rendah sekitar 2-3 \% per bulan, tinggi sekitar $15-20 \%$ per bulan.

2. Tingkat perputaran karyawan (labour turn over)

Tingkat perputaran karyawan adalah aliran masuk (accession) dan keluarnya (separation) sumber daya manusia. Tingkat perputaran karyawan menunjukkan stabil tidaknya suatu perusahaan.

Soenarno (2006:32) memberikan pengertian tentang reservasi adalah pemesanan kamar dihotel. Sedangkan menurut Damardjati (2001:36) reservasi bisa disamakan arti dengan booking yang memiliki pengertian pemesanan tempat (direstoran, night-club, theater, shows, atau tempat duduk dalam pesaawat, kereta api atau kamar hotel dan sebagainya.

\section{METODE PENELITIAN}

Penelitian ini dilakukan di CV. CAN Tour and Travel. Berlokasi di Jalan Tukad Buaji GG. Teratai Jingga no 5E, Denpasar. Peneliti memilih CV. CAN Tour and Travel karena biro perjalanan ini masih termasuk biro perjalanan kecil yang dalam manajemen sumber daya manusia masih hanya memiliki beberapa tenaga kerja yang bekerja merangkap di bidang yang berbeda.

Definisi Operasional Variabel atau DOV dalam penelitian ini adalah analisis perencanaan dan pengembangan dilihat dari manajemen sumber daya manusia yang ada dalam CV.CAN Tour and Travel, seperti struktur organisasi,analisis jabatan, jumlah tenaga kerja yang dibutuhkan dan kualifikasi tenaga kerja yang dibutuhkan.

Pengumpulan data dilakukan dengan cara observasi, wawancara, dan studi kepustakaan. Kemudian yang menjadi informan kunci dan informan pangkal adalah tenaga kerja yang mengerjakan pekerjaan merangkap. Analisis data dilakukan secara kuantitatif yaitu dengan menganalisis beban kerja dan menganilisis kebutuhan tenaga kerja.

\section{PEMBAHASAN \\ Reservasi CV. CAN Tour and Travel}

Pada departemen reservasi terdapat 2 (dua) orang tenaga kerja yang ada,, yaitu reservasi dan ticketing. Tenaga kerja reservasi disini lebih mengkhususkan kepada tanggung jawabnya atas pemesanan tamu dalam pembelian produk tour dan akomodasinya. Berbeda dengan ticketing yang khusus kepada pemesanan bangku pesawat dan laporan-laporan didalamnya. Hal ini dilakukan agar setiap tenaga kerja di departemen ini dapat melakukan tugas dan tanggung jawabnya dengan baik.

Dari hasil wawancara yang didapat mengenai alur kerja reservasi, ditemukan bahwa sebagian besar tamu atau pelanggan CV. CAN Tour and Travel melakukan pemesanan online dengan semakin majunya IT saat ini yang memudahkan para wisatawan tersebut. Untuk standar operasional perusahaan ini belum tertulis, namun ditetapkan bahwa proses reservasi melayani tamu secara langsung adalah 45 menit per orang, dan untuk pemesanan online kira- kira 220 menit.

Kebutuhan Tenaga Kerja Reservasi CV. CAN Tour and Travel

Jumlah kebutuhan tenaga kerja perlu ditentukan agar tenaga kerja yang ada dalam perusahaan tersebut dapat menjalankan tugasnya 
dengan baik dimana terdapat keseimbangan antara jumlah tenaga kerja tersebut dan beban kerja yang menjadi tanggung jawabnya kepada perusahaan.

Untuk menghitung beban kerja yang diterima karyawan reservasi, maka perlu diketahui waktu yang diperlukan untuk menyelesaikan suatu pekerjaan. Waktu kerja yang dibutuhkan untuk melakukan reservasi pemesanan tamu secara online maupun langsung adalah 690 menit. Sedangkan waktu kerja di kantor setiap harinya adalah 8 (delapan) jam atau sama dengan 480 menit. Jadi setiap harinya reservasi CV. CAN Tour and Travel kekurangan waktu kerja sebanyak 200 menit atau kurang lebih 3 jam.

Selain itu, jumlah hari kerja efektif juga dapat membantu mengetahui kebutuhan tenaga kerja yang diperlukan di perusahaan ini yaitu dengan mengurangi hari dalam setahun dengan jumlah kantor tutup lalu dikurangi jumlah hari libur agama yang dianut karyawan tersebut dan dikurangi jumlah cuti yang telah ditentukan perusahaan yaitu 292 hari.

\section{Analisis Beban Kerja}

Untuk lebih mengetahui jumlah kebutuhan tenaga kerja reservasi pada CV. CAN Tour and Travel maka akan digunakan analisis beban kerja. Berdasarkan penghitungan dalam menggunakan analisis beban kerja maka jumlah tenaga kerja reservasi di Reservation Department pada CV. CAN Tour and Travel adalah 2 orang, karena angka yang didapat diasumsikan bahwa jumlah tenaga kerja staff reservasi yang hanya satu pada saat ini tidak dapat mengerjakan tanggung jawabnya dengan baik dalam pemesanan langsung juga online sekaligus.

\section{Analisis Kebutuhan Tenaga Kerja ( Work Force Analysis )}

Pada analisis ini jumlah kebutuhan tenaga kerja ditentukan dengan beban kerja, jumlah ketidakhadiran dan perputaran tenaga kerja. Perputaran tenaga kerja reservasi di Reservation Department pada CV.CAN Tour and Travel dapat langsung dikatakan bahwa hanya sebesar 0 $\%$ karena perusahaan ini belum mengalami pergantian, pengurangan maupun penambahan tenaga kerja reservasi.
Dengan diperhitungkan jumlah tenaga kerja reservasi di Reservation Department pada CV. CAN Tour and Travel ditemukan bahwa jumlah tenaga kerja reservasi ini membutuhkan 2 orang reservasi yang bekerja setiap harinya. Ditemukan hasil penelitian bahwa tenaga kerja reservasi pada CV. CAN Tour and Travel didapatkan bahwa jumlah kebutuhan tenaga kerja reservasi yang dibutuhkan CV. CAN Tour and Travel adalah 2 orang, dan jumlah tersebut tidak sesuai dengan tenaga kerja yang ada saat ini yang adalah 1 (satu) orang. Dapat diasumsikan bahwa penambahan jumlah tenaga kerja harus dilakukan mengingat tenaga kerja reservasi ini kekurangan waktu kerja 3 (tiga) jam yang saat ini sisa pekerjaan dilakukan diluar jam bekerja.

\section{SIMPULAN DAN SARAN Simpulan}

Dari hasil penelitian ini dapat diambil kesimpulan bahwa CV. CAN Tour and Travel untuk saat ini memiliki 11 karyawan. Dengan didalamnya memiliki 2 orang pada Reservation Department dimana salah satunya bertanggung jawab pada ticketing dan lainnya untuk reservasi hotel dan tour. Penghitungan untuk mengetahui jumlah tenaga kerja yang dibutuhkan pada $\mathrm{CV}$. CAN Tour and Travel ini menggunakan analisis kebutuhan tenaga kerja yang didalamnya juga menganalisis beban kerja dan jumlah ketidakhadiran selama 1 (satu) tahun bekerja tenaga kerja staff reservasi. Setelah dihitung, untuk saat ini jumlah tenaga kerja reservasi yang dibutuhkan adalah 2 orang. Hal tersebut tidak sesuai dengan kenyataan perusahaan saat ini yang hanya memiliki 1 orang di reservasi. Sehingga dengan demikian dapat dikatakan perlu 3 orang dalam Reservation Department, 2 orang reservasi dan 1 orang pada ticketing.

\section{Saran}

Dari kesimpulan diatas, maka dapat disarankan perusahaan yang hanya memiiliki 11 karyawan ini perlu menambah satu orang tenaga kerja di bagian staff reservasi untuk menangani pemesanan langsung maupun online. Hal ini ditujukan agar tanggung jawab yang seharusnya dilakukan dapat berjalan lebih baik lagi agar perencanaan dalam pengembangan perusahaan di aspek tenaga kerja dapat bertumbuh. Berikut 
adalah hal - hal yang perlu diperhatikan guna merencanakan pengembangan, yaitu : (1)Perlu dilakukan pelatihan yang sesuai dengan kebutuhan kemampuan sebagai reservasi secara berkala.(2)Dapat juga terlibat dalam berbagai seminar yang berhubungan dengan bidang usaha ini untuk meningkatkan rasa kerjasama yang baik dengan perusahaan yang lain.(3)Dapat dilakukan pengarahan atau briefing secara berkala.

\section{DAFTAR PUSTAKA}

Anonim. Undang-Undang Republik Indonesia nomor 10 tahun 2009 tentang kepariwisataan.

Bali dalam angka 2010. Data Jumlah Biro Perjalanan Wisata di Provinsi Bali Tahun 2010.

BPS. 2010. Jumlah Kunjungan Wisatawan Mancanegara yang Langsung ke Bali Tahun 2005- 2010. Denpasar: Badan Pusat Statistik Provinsi Bali.

Budiasri, Ni Luh. 2007. "Analisis Kebutuhan Tenaga Kerja Cool's Operator pada Sport Recreation and Entertainment Department di Grand Mirage Resort \& Spa Bali".Laporan Akhir. Fakultas Pariwisata Universitas Udayana.

Damardjati, RS. 2001. Istilah - istilah Dunia Pariwisata. Jakarta : Pradnya Paramita.

Handoko , Hani. 2012. Manajemen Personalia \& Sumber Daya Manusia. Yogyakarta : BPFE

Indrawati , Linna. 2005. "Analisis Kebutuhan Tenaga Kerja Reservasi Qantas Holidays pada PT. Tour East Indonesia”. Laporan
Akhir. Fakultas Pariwisata Universitas Udayana.

Kusumayadi, dan Endar Sugiarto. Metodologi Dalam Bidang Kepariwisataan. Jakarta: Gramedia Pustaka Utama.

Mathis, R dan Jackson, John H. 2006. Human Resources Management (Track MBA series/terjemahan). Jakarta : Prestasi Pusaka.

Marpaung, Happy. 2000. Pengetahuan Kepariwisataan. Bandung : Alfabeta.

Mullins, Laurier J. 2005. Management and Organizational Behavior. Prentice Hall: Edinburg Gate Harlow

Rais, S., dan Soembodo, B. . 1997. Analisis Jabatan Untuk Meningkatkan Efektivitas Kerja. Surabaya : Airlangga University Press.

Siagian, Sondang P. 2002. Manajemen Sumber Daya Manusia. Jakarta : Bumi Aksara

Suartana P., I Gusti Lanang. 2004. "Analisis Kebutuhan Tenaga Kerja Operasional di Dinas Kesehatan Kabupaten Badung”. Tesis. Program Studi Manajemen; Program Pascasarjana.

Soenarno, Adi. 2006. Front Office Management. Yogyakarta: CV. Andi Offset (Penerbit Andi)

Utama, Mudiartha W.2001. Manajemen Sumber Daya Manusia. Denpasar : Universitas Udayana.

Winaya, Kuna. 1994. Manajemen Sumber Daya Manusia (lanjutan). Denpasar : Universitas Udayana. 